\title{
7. BOREHOLE TELEVIEWER LOG OF HOLE 395A ${ }^{1}$
}

\author{
Stephen H. Hickman and Joseph F. Svitek, U.S. Geological Survey \\ and \\ Marcus G. Langseth, Lamont-Doherty Geological Observatory ${ }^{2}$
}

\begin{abstract}
During Leg 78B, a borehole televiewer survey was conducted in a 609-m-deep hole drilled near the Mid-Atlantic Ridge at DSDP Site 395. Although the resolution of the borehole televiewer during this cruise was degraded by ship heave and a reduced transducer rotation speed, the borehole televiewer log does provide a fairly complete record of the variations in borehole wall smoothness and geometry in Hole 395A. An excellent correlation was observed, for example, between the reflectance (or brightness) of the borehole televiewer log and the hole diameter as shown by a 3-arm caliper survey conducted during this cruise. Sections of the well shown by the caliper log to have a smooth wall and a diameter close to the drill-bit size are represented in the televiewer log as high-reflectivity zones. Conversely, sections of the hole where the caliper indicates a borehole that is rough or significantly larger than the bit size appear on the televiewer log as low-reflectivity zones. Also, in some parts of the well, lithologic variations were detected by the borehole televiewer, and zones of pillow basalts or massive flows that had been identified in the core were discernible in the log.
\end{abstract}

\section{INTRODUCTION}

Accurate delineation of the stratigraphy of the ocean crust is essential to a proper understanding of the petrogenesis and structural evolution of young oceanic lithosphere. In addition, direct measurements of the distribution and geometry of natural fractures are needed for successful modeling of phenomena such as seismic wave propagation (Hyndman and Drury, 1976; Schreiber and Fox, 1976; Zoback and Anderson, 1982) and hydrothermal circulation in the oceanic lithosphere (Anderson and Zoback, 1982; Langseth et al., this volume). Recovery of core from holes drilled in the ocean floor has proven invaluable for studying the petrology of the ocean floor; but the percentage of core recovered in highly fractured rock is usually quite poor, and delineation of the stratigraphy and structural fabric of the ocean crust from cores alone is correspondingly limited. This is especially so when one attempts to obtain a truly representative sample of the natural fracture population at a particular site, since cores tend to disintegrate when they encounter large-aperture or poorly cemented fractures. We conducted an ultrasonic borehole televiewer $\log$ (described herein) during DSDP Leg 78B, in an attempt to define better the lithostratigraphy, structure, and fracture population of the upper ocean crust in Hole 395A. The borehole televiewer has been successfully used in studies of the lithostratigraphy and structure of young ocean crust near the Costa Rica Rift (Zoback and Anderson, 1982), as well as in studies of the distribution and geometry of natural fractures on land (Seeberger and Zoback, 1982).

\footnotetext{
${ }^{1}$ Hyndman, R. D., Salisbury, M. H., et al., Init. Repts. DSDP, 78B: Washington (U.S. Govt, Printing Office).

2 Addresses: (Hickman, present address) Dept. of Earth, Atmospheric, and Planetary Sciences, Massachusetts Institute of Technology, Cambridge, MA 20139; (Svitek) U.S. Geological Survey, 345 Middlefield Road, Menlo Park, CA 94025; (Langseth) Lamont-Doherty Geological Observatory of Columbia University, Palisades, NY 10964.
}

\section{METHOD}

The borehole televiewer is a wireline logging tool that provides a continuous, oriented, ultrasonic image of a borehole wall. The tool used on Leg 78B (manufactured by Simplec, Inc., and described by Zemanek et al., 1970) consists of a transducer mounted on a motordriven shaft and aimed at the borehole wall (Fig. 1A). The transducer rotates three times per second while generating an approximately $1.2-\mathrm{MHz}$ pulse 1800 times per second. The tool is pulled up the hole at a speed of $1.5 \mathrm{~m} / \mathrm{min}$. on a standard wireline logging cable. In this manner, the beam from the transducer describes a helical path up the borehole wall. The reflected energy that returns to the transducer modulates the intensity of a trace on a cathode ray tube at the surface, so that a bright trace corresponds to a good reflection and a dark trace indicates a scattered or absorbed signal. One revolution of the transducer corresponds to one trace on the cathode ray tube, and the initiation of each trace is controlled by a fluxgate magnetometer. This magnetometer is mounted on the same shaft as the transducer (see Figure 1A) and generates a trigger pulse each time the transducer passes magnetic north. Successive traces move up the cathode ray tube at a fixed rate as the tool is slowly pulled uphole. This display is photographed using an oscilloscope camera, and a separate image of each $1.5-\mathrm{m}$ section of the hole is produced.

Characteristic patterns are produced by the fractures, voids, washouts, and other wall features, and the orientation of these features relative to magnetic north may be determined from the borehole televiewer $\log$ (see Figure 1B). The unprocessed sonic signal from the tool and the trigger pulse from the fluxgate magnetometer are recorded on video tape for additional processing at a later date.

The borehole televiewer $\log$ is essentially a record of borehole wall smoothness. Smooth, unfractured zones in the borehole wall will be highly reflective and will appear in the televiewer log as uniformly bright zones. The more fractured, porous, or washed-out areas, however, will scatter the signal and appear as dark areas on the record. The resolution of the borehole televiewer is controlled by such factors as hole diameter, acoustic impedance of the well fluid, and the presence of large-scale irregularities in the borehole wall. In Hole 395A, the resolution of the borehole televiewer is probably on the order of 5 to $10 \mathrm{~mm}$. A televiewer $\log$ can be used to determine the locations of contacts between major lithologic units; the form, orientation, and distribution of natural discontinuities such as fractures and the rims of basalt pillows; and the nature and extent of irregularities produced in the borehole wall by drilling. This information can also be used to estimate relative permeability and to evaluate hole conditions, as a guide to conducting in situ permeability and aquifer pressure tests using an inflatable packer (see Hickman et al., this volume). 
A

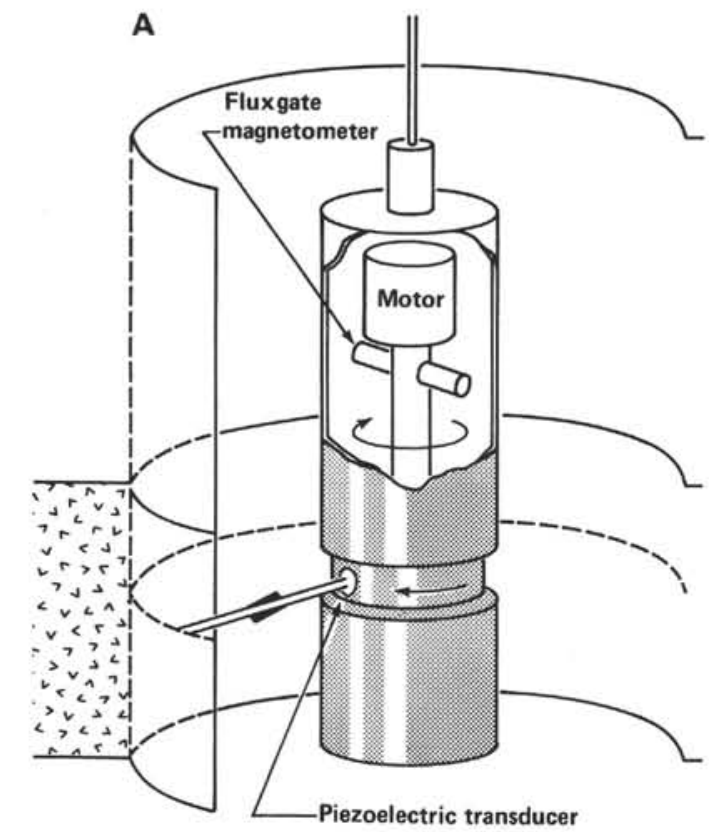

B

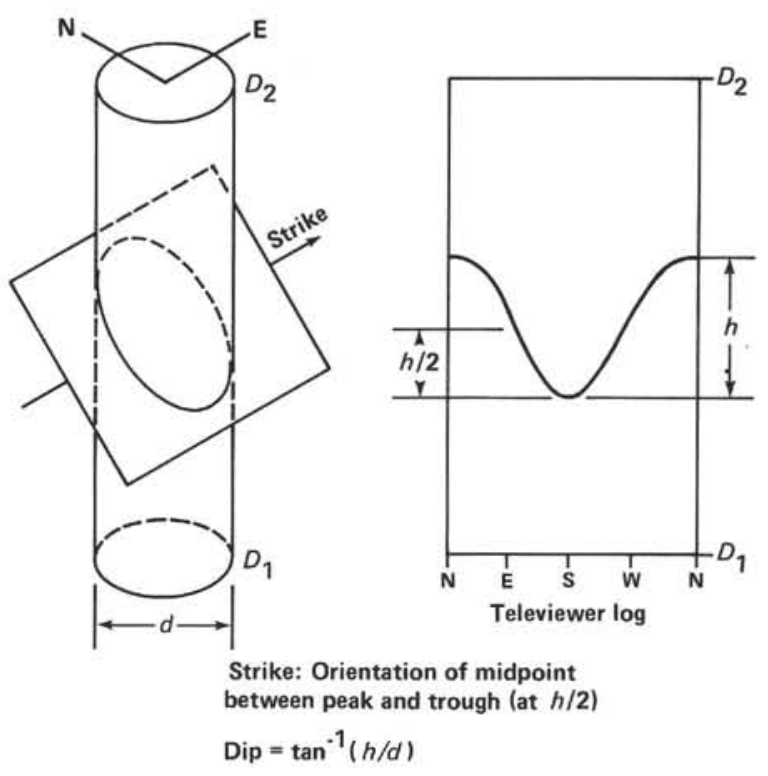

Figure 1. A. Schematic of borehole televiewer tool in operation, showing piezoelectric transducer, fluxgate magnetometer, and driving motor. B. Sinusoidal signature of a planar feature intersecting the borehole on the borehole televiewer log and the manner in which the strike and dip of that feature may be determined (after Zemanek et al., 1970).

\section{OPERATIONS}

Before the borehole televiewer log was run, Hole 395A was flushed with seawater to purge any drilling mud and cuttings that may have been left in the hole when it was first drilled during Leg 45. This was done to minimize scatter of the transducer signal by debris suspended in the hole. In testing the tool in conjunction with the ship's 9-km wireline before arriving at the site, the amplitude of the magnetometer signal arriving at the surface was found to be too small $(0.2 \mathrm{~V})$ to trigger the surface electronics. Conductors were than paired to the dc power/ compass circuitry in the tool, reducing the line resistance by half and resulting in a usable magnetometer trigger of $0.4 \mathrm{~V}$.

While the televiewer was lowered down the drill pipe to begin logging, the tool was periodically checked to ascertain that it was still functioning properly. During this period the tool functioned correctly, but later, when logging was started at the bottom of the hole, the rotating mechanism was found to be turning at only about one revolution per second, or one third of normal speed. After unsuccessful attempts to remedy the situation (by increasing the ac power to the tool, using the televiewer control panel), the log was run in the usual manner, but with the gain on the horizontal axis of the cathode ray tube reduced to compensate as much as possible for the reduced sweep rate. With only one third of the normal vertical sweep density, however, some resolution was lost. Unfortunately, the tool performed normally when returned to the surface, so it was difficult to diagnose the problem. A check before the log was run showed that $60 \mathrm{~V}$ ac (under load) was reaching the motor in the tool through the ship's wireline. Although this proved sufficient for normal tool operation on the surface, it was apparently inadequate downhole. The transducer, magnetometer, and motor assembly occupy an oil-filled chamber in the tool which is automatically maintained at the same pressure as the water surrounding the tool. It is believed that an increase in oil viscosity caused by high pressure and low borehole temperatures (see Becker et al., this volume) may have resulted in the reduced motor speed.

The most serious problem in running the televiewer log on this cruise, however, was ship heave. The swell was about $2 \mathrm{~m}$ in amplitude with a 10 -s period while the televiewer log was being run, producing large vertical oscillations of the logging tool during the operation. Owing to the relatively slow speed at which the televiewer log is run $(1.5 \mathrm{~m} / \mathrm{min}$.), this produced extreme overprinting and stretching of the scanned image, and destroyed much vertical continuity in the televiewer log. Since this problem is shared by other logging operations on the Glomar Challenger, some form of wireline heave-compensation system should be seriously considered for future drilling and logging operations.

\section{DATA AND DISCUSSION}

A reduced photographic copy of the televiewer log obtained in Hole 395A is presented in Figure 2. The depths shown in Figure 2 are given in meters below the seafloor to facilitate comparison with the lithologic units described in Melson, Rabinowitz, et al. (1979). To facilitate comparison between televiewer reflectance and hole diameter, we made readings of the intensity of the light reflected from each 3-m section of the borehole televiewer log under illumination of constant intensity, using a standard photographic light meter. The results from these measurements, together with the caliper log from this hole, are shown in Figure 3. Since the intensity of light reflected from the borehole televiewer log under such circumstances depends upon a variety of factors (such as the intensity and relative position of the light source and the gain settings on the televiewer surface electronics), the reflectance scale in Figure 3 is, of necessity, arbitrary.

As is evident in Figure 3, the correlation between televiewer reflectance and hole diameter is quite good. Sections of the hole shown by the caliper log to have a diameter close to that of the drill bit (about $28 \mathrm{~cm}$ ) are represented on the televiewer log as high-reflectivity (light) zones. Examples of this can be seen at 112-163, 177-199, $352-407,511-554$, and 562-599 m sub-bottom. Conversely, places where the caliper log shows the borehole wall to be rough or the hole diameter to be significantly greater than the drill-bit diameter appear on the televiewer log as low-reflectively (dark) zones. Examples of this can be seen at 163-177, 199-247, 407-427, and 554-562 m sub-bottom. 

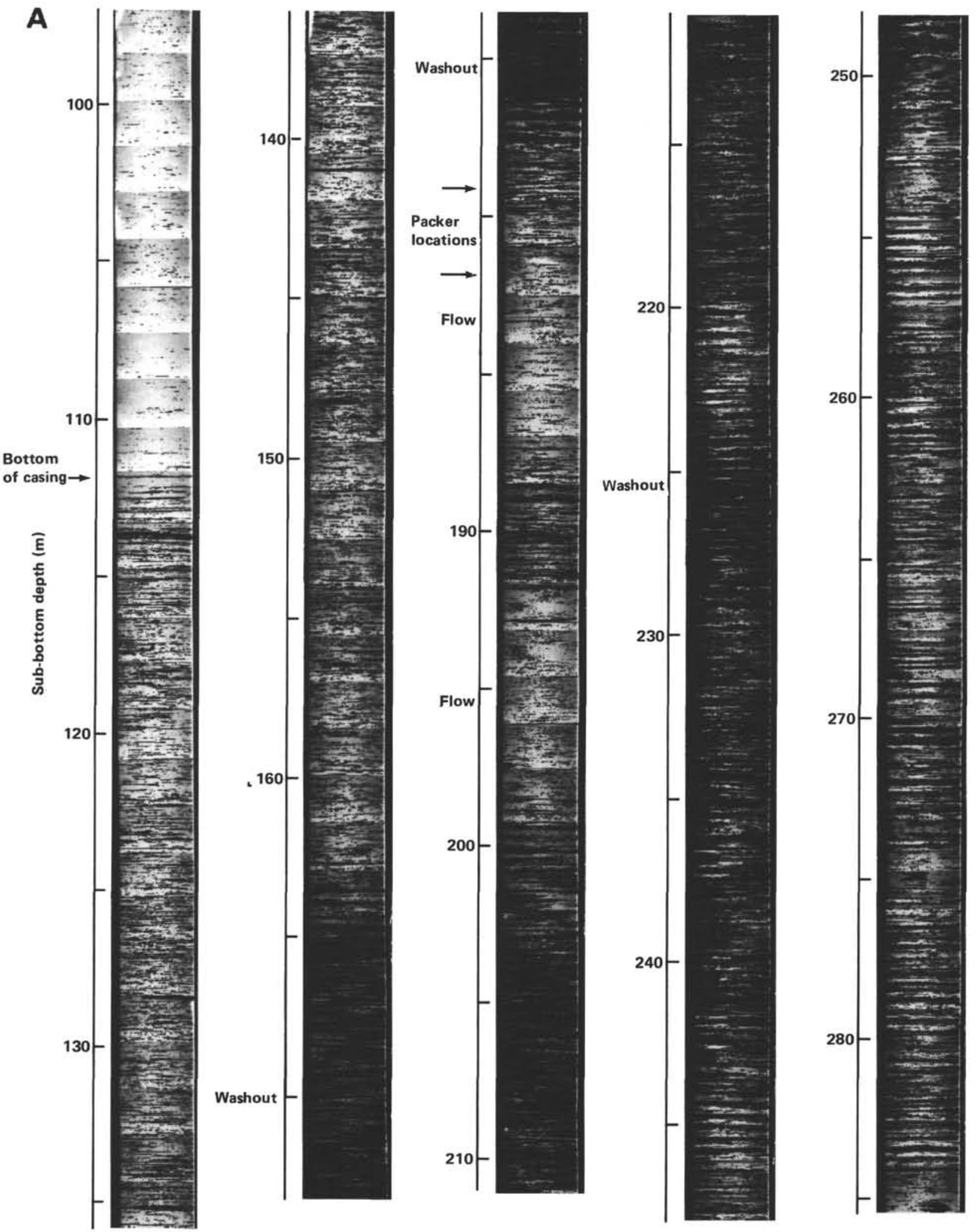

Figure 2. A, B, and C. Reduced photographic reproductions of borehole televiewer log from Hole 395A. The left- and right-hand margins of the log correspond to magnetic north. Prominent washouts seen on the caliper log (Mathews et al., this volume) and basalt flows seen in the core (Melson, Rabinowitz, et al., 1979) are indicated, as are the locations for the packer tests conducted by Hickman et al. (this volume). 

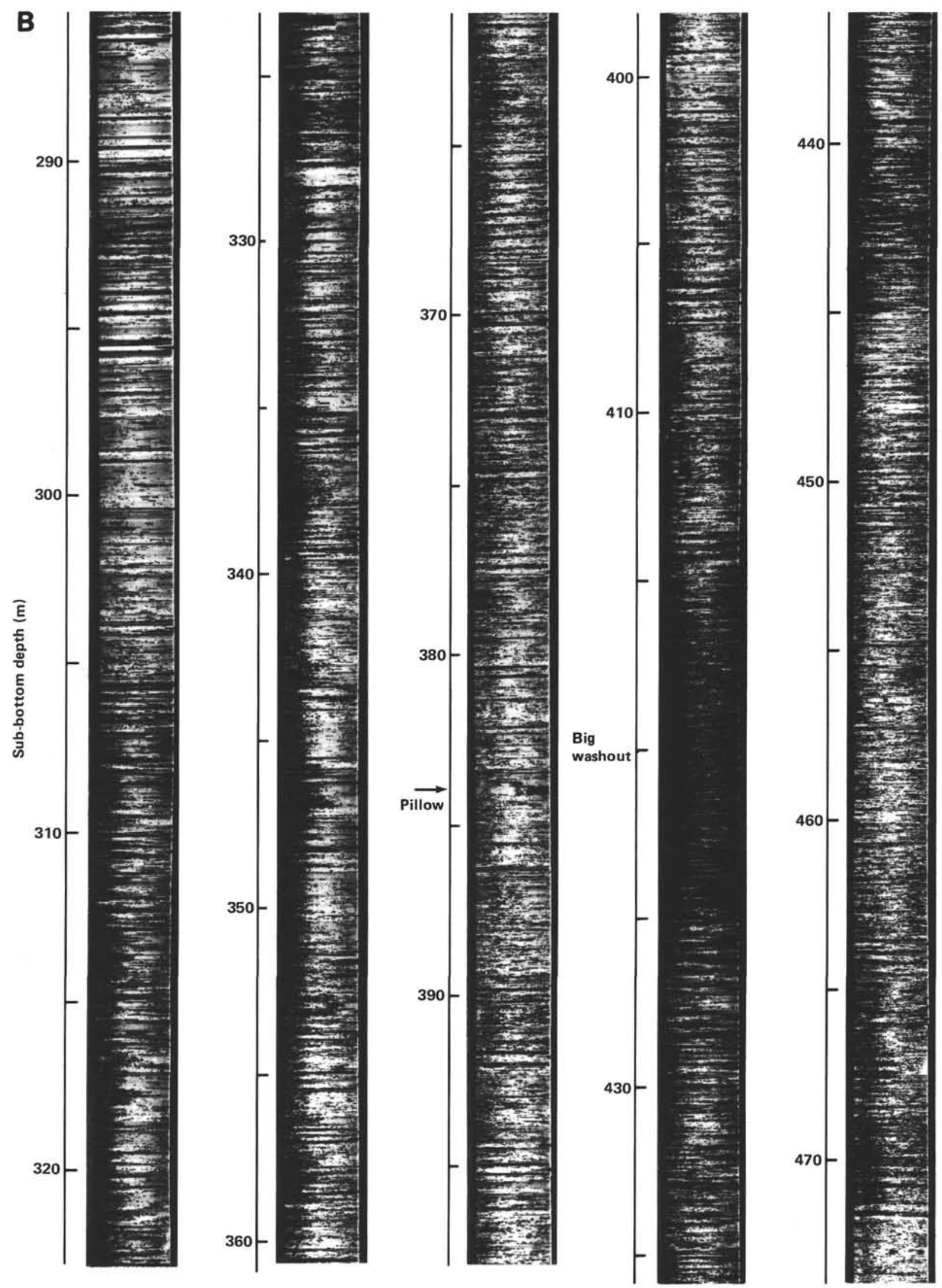

Figure 2. (Continued). 
C

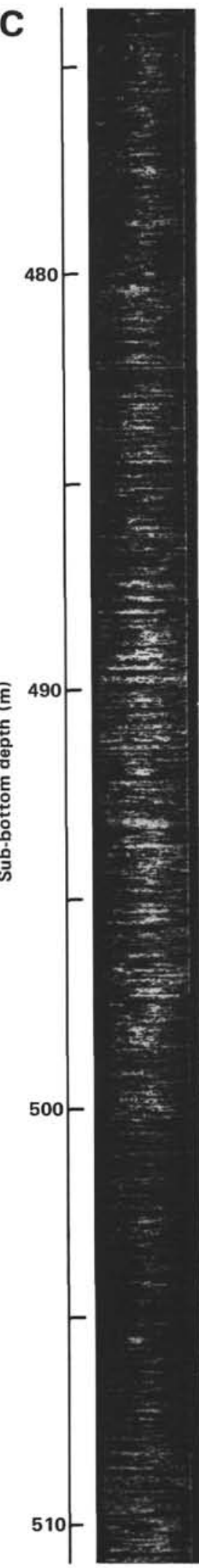

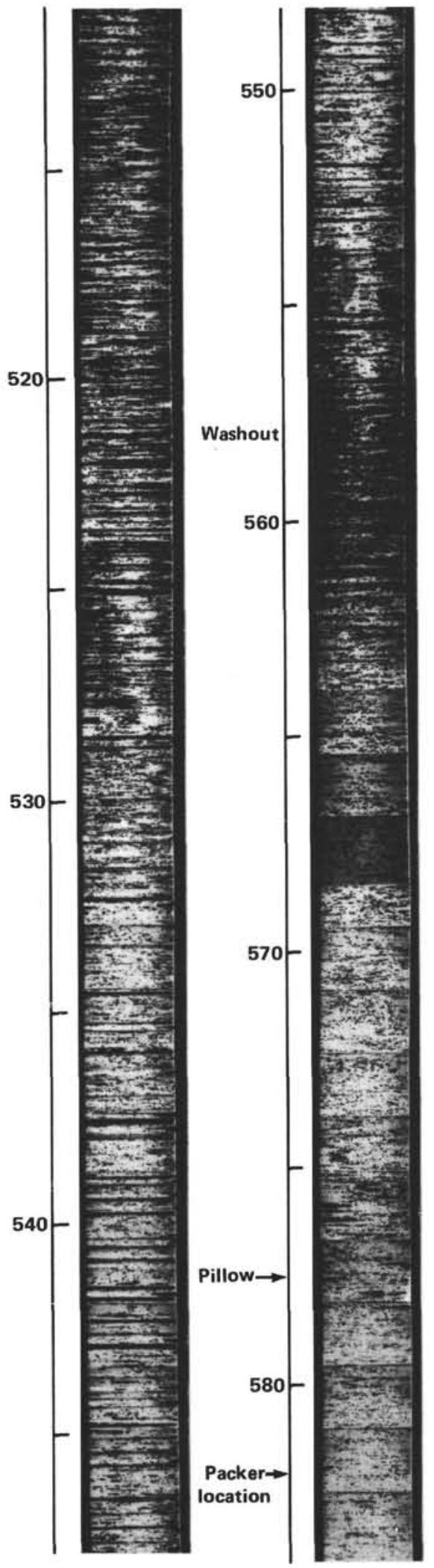

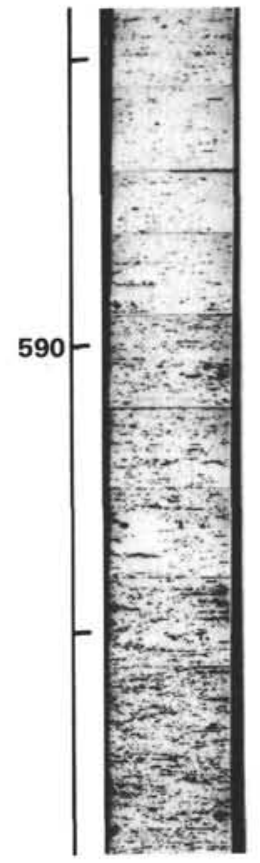

Figure 2. (Continued). 


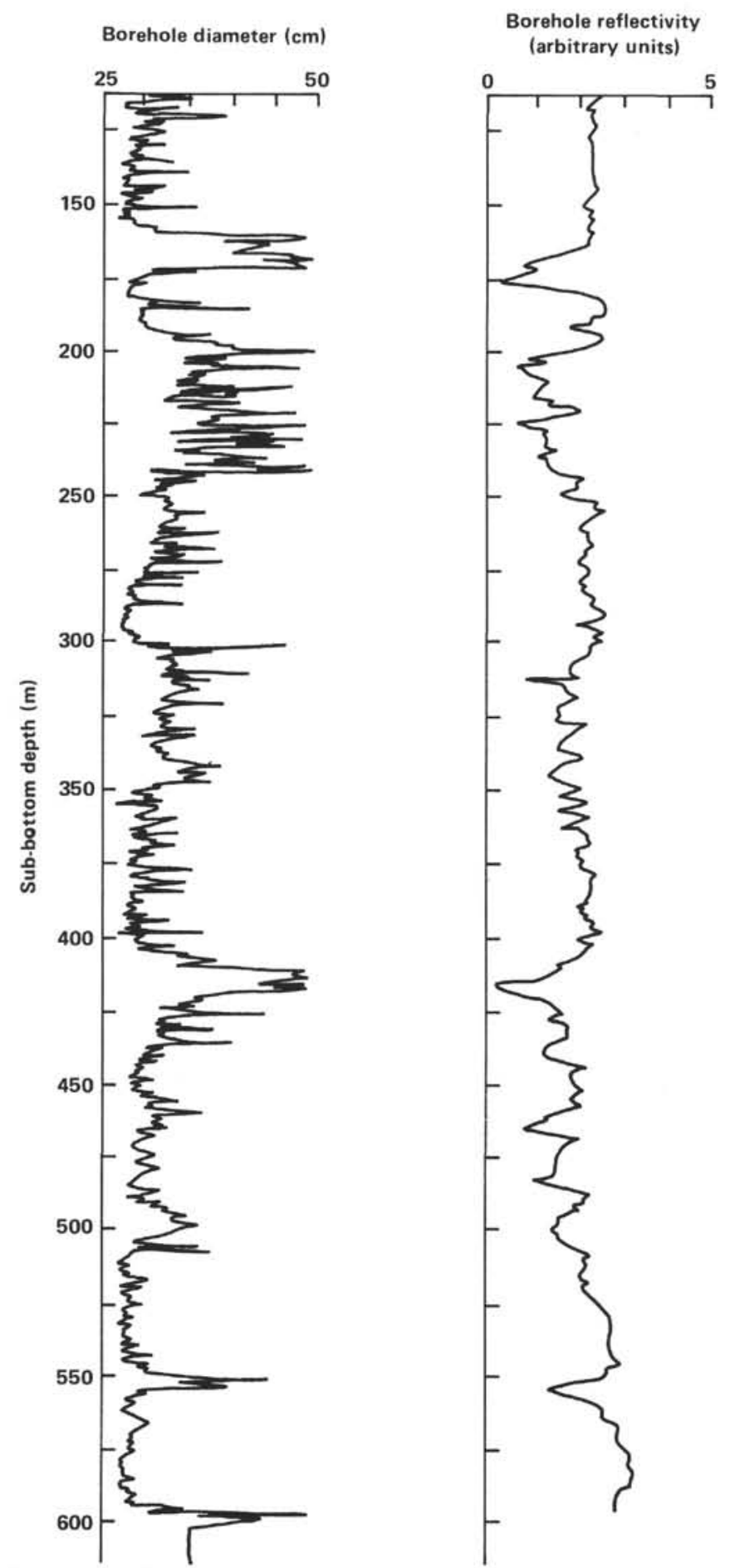

Figure 3. Comparison of borenole diameter determined from caliper $\log$ (Mathews et al., this volume) and borehole reflectivity (described in text) determined from televiewer log in Hole 395A.

The variations in reflectance recorded in the televiewer $\log$ can also be correlated with some of the lithologic units defined by Melson, Rabinowitz, et al. (1979) when Hole 395A was originally drilled during Leg 45 . Massive flows of phyric basalt were identified, for example, in the interval $174-211 \mathrm{~m}$ sub-bottom, and are clearly recognizable in the borehole televiewer log as bands of high reflectance (see Figs. 2A and 3). This flow was chosen by Hickman et al. (this volume) as the location for several packer experiments because of the smoothness of the borehole wall at this depth. The televiewer log also indicates a high-reflectivity zone (which includes one prominent washout) extending from about $511 \mathrm{~m}$ subbottom to the bottom of the log at $599 \mathrm{~m}$, with reflectivity gradually increasing downward (Fig. 3). This correlates well with two units, between 509 and $608 \mathrm{~m}$ subbottom, consisting of breccias and aphyric pillow lavas well cemented by hydrothermal alteration products. The increase in televiewer reflectivity below $511 \mathrm{~m}$ is also roughly coincident with an increase in core recovery observed by Melson, Rabinowitz, et al. (1979) below about $477 \mathrm{~m}$ in the hole. The porosity-related geophysical logs such as resistivity, neutron porosity, sonic velocity, and gamma density indicate massive, low-porosity rock at the bottom of the hole (Mathews et al., this volume). In addition, permeability tests performed at $583 \mathrm{~m}$ sub-bottom by Hickman et al. (this volume) showed the entire lower section of the hole to be nearly impermeable-a finding which is in agreement with the low porosity indicated by the geophysical logs and the high televiewer reflectivity.

Most of the hole penetrates thick sections of highly fractured and weakly cemented pillow lavas (Melson, Rabinowitz, et al., 1979). The televiewer reflectivity is low, and the hole tends to be larger than the drill-bit diameter in these zones (Fig. 3), presumably because the wall material is readily broken away during drilling. Examples of such enlarged zones in the pillow lavas include the intervals 211-233, 302-349, and 407-507 m sub-bottom. These sections are marked by numerous dark patches and horizontal streaks on the televiewer log, corresponding to small recesses in the borehole wall and perhaps representing washouts around individual pillows. Small-scale elliptical features, which may also represent pillows, are discernible on the televiewer log (Fig. 2) at $384,510,527$, and $578 \mathrm{~m}$ sub-bottom.

Other features in the televiewer log include broad, vertical, dark bands extending over large intervals of the record. A good example appears in the section from 307 to $361 \mathrm{~m}$ sub-bottom. These bands are thought to arise from the tool being off center in the hole when the diameter of the hole exceeds that of the fully extended televiewer centralizer springs.

\section{CONCLUSIONS}

Although wave-induced oscillations of the borehole televiewer, together with the unusually slow transducer rotation speed, resulted in a log of limited resolution, the televiewer log does provide a complete record of the variations in borehole wall smoothness and geometry in Hole 395A. An excellent correlation was observed between televiewer log reflectance (or image brightness) and hole diameter as indicated on the caliper log of Mathews et al. (this volume). In addition, in some zones, a good correlation with lithology is evident, and features were recorded in the borehole televiewer log that are indicative of the basalt flows and pillows recovered in the core when Hole 395A was originally drilled. 


\section{ACKNOWLEDGMENTS}

We would like to thank the crew of the Glomar Challenger, as well as the staff of the Deep Sea Drilling Project, for their assistance in conducting the borehole televiewer log. This manuscript was reviewed by Tom Urban and Gretchen Zwart. This study was partially supported under NSF grant OCE 78-27026.

\section{REFERENCES}

Anderson, R. N., and Zoback, M. D., 1982. Permeability, underpressures, and convection in the oceanic crust near the Costa Rica Rift, Eastern Equatorial Pacific. J. Geophys. Res., 87:2860-2868.

Hyndman, R. D., and Drury, M. J., 1976. The physical properties of oceanic basement rocks from deep drilling on the Mid-Atlantic Ridge. J. Geophys. Res., 81:4042-4059.

Melson, W. G., Rabinowitz, P. D., et al., 1979. Site 395: $23^{\circ}$ N, MidAtlantic Ridge. In Melson, W. G., Rabinowitz, P. D., et al., Init. Repts. DSDP, 45: Washington (U.S. Govt. Printing Office), 131-264.
Schreiber, E., and Fox, P. J., 1976. Compressional wave velocities and mineralogy of fresh basalts from the Famous Area and the Oceanographer Fracture Zone and the texture of Layer 2A of the oceanic crust. J. Geophys. Res., 81:4071-4076.

Seeburger, D. A., and Zoback, M. D., 1982. The distribution of fractures and joints at depth in crystalline rocks. J. Geophys. Res., 87: 5517-5534.

Zemanek, J., Glenn, E., Norton, C. J., and Cardwell, R. L., 1970. Formation evaluation by inspection with the borehole televiewer. Geophysics, 35:254-269.

Zoback, M. D., and Anderson, R. N., 1982. Ultrasonic borehole televiewer investigation of oceanic crustal layer $2 \mathrm{~A}$, Costa Rica Rift. Nature, 295:375-379.

Date of Initial Receipt: June 6, 1983

Date of Acceptance: July 20, 1983 